\title{
The basement of residential buildings as part of radon preventive measures
}

\author{
Teresa Kusionowicz ${ }^{1, *}$ \\ ${ }^{1}$ Faculty of Architecture, Cracow University of Technology, 31-155 Kraków, 24 Warszawska St., Poland
}

\begin{abstract}
The Directive 2013/59/Euratom was adopted by the Council of the European Union in 2013. It lays down basic safety standards for protection against the dangers from exposure to ionising radiation. The directive obliges our country to adopt the laws, regulations and administrative provisions necessary for its implementation. According to research conducted by the Institute of Nuclear Physics in Kraków, radon constitutes the largest source of ionising radiation a resident of our country is exposed to. Its share reaches almost $40 \%$ of the annual dose. Inhalation of radon and products of its decay in rooms constitutes a significant part of the dose of ionising radiation whose source is radon. Residential premises are the rooms in which we spend nearly $60 \%$ of our life in our climate zone. Environmental studies conducted in these rooms demonstrate that the concentration of radon in their interior is in many cases greater than its concentration outside the building. This issue is dealt with in Article 74 of the Directive 2013/59/Euratom. It recommends taking action to prevent long-term health risks resulting from exposure to radon in residential and public premises. Architectural and construction solutions applied in buildings play a significant role in the prevention of such dangers. One of the radon preventive measures in the indoor environment is the design of basements in residential buildings.
\end{abstract}

\section{Introduction}

Due to the high social costs incurred for the treatment of people and the results of research conducted by the medical community, it becomes necessary to involve architects in interdisciplinary activities as part of preventative health care. It was already Vitruvius who claimed that medical knowledge is to a certain extent an indispensable element of the architect's professional skills. Also today, medical knowledge should be an indispensable element of the architect's professional skills so that human biological needs could be met in a proper way. This knowledge should be systematically updated and take account of the current level of knowledge in the field of environmental medicine. These considerations aim at selecting such architectural and construction solutions that do not cause changes that are detrimental to human health in the indoor environment and at the same time protect that environment from the impact of factors harmful to our body. In terms of preventative health care in architecture, residential premises in which we spend nearly $60 \%$ of our life in our

\footnotetext{
${ }^{*}$ Corresponding author: tkusionowicz@pk.edu.pl
} 
climate zone require particularly careful design. While designing a building, architects determine its form and functional layout, but also, to a significant extent, the environmental conditions in its interior. Due to the significant amount of time people spend in buildings, the so-called internal environmental conditions have a huge impact on our health.

\section{Physical health risks in residential premises}

Biological, chemical and physical factors that pose significant threats to human health accumulate in the indoor environment. [1] While no significant new reports concerning biological and chemical hazards have appeared lately, there has been clear progress in recent years in the area of knowledge related to physical threats in the internal environment. This progress concerns both physical hazards of thermal and non-thermal nature. In terms of the latter, mainly in the field of radiation phenomena, i.e. ionising radiation. [2] In the light of medical research, radon has been recognized by the World Health Organization (WHO) as a risk factor for human health as part of ionising radiation. [3] A comparison of the percentage share of particular types of radiation affecting the human body shows that radon found in the air poses the greatest threat in relation to its other sources. [4] According to the latest research conducted by Polish physicists, the share of radon and thoron constitutes about $40 \%$ of the annual dose of ionising radiation that amount to 3.3 million sieverts for Polish citizens. [5] According to Western studies, the share of radon in the average annual dose of ionising radiation affecting humans is up to 50\%. [6] (Fig.1).

\section{Average Annual Dose to UK Population}

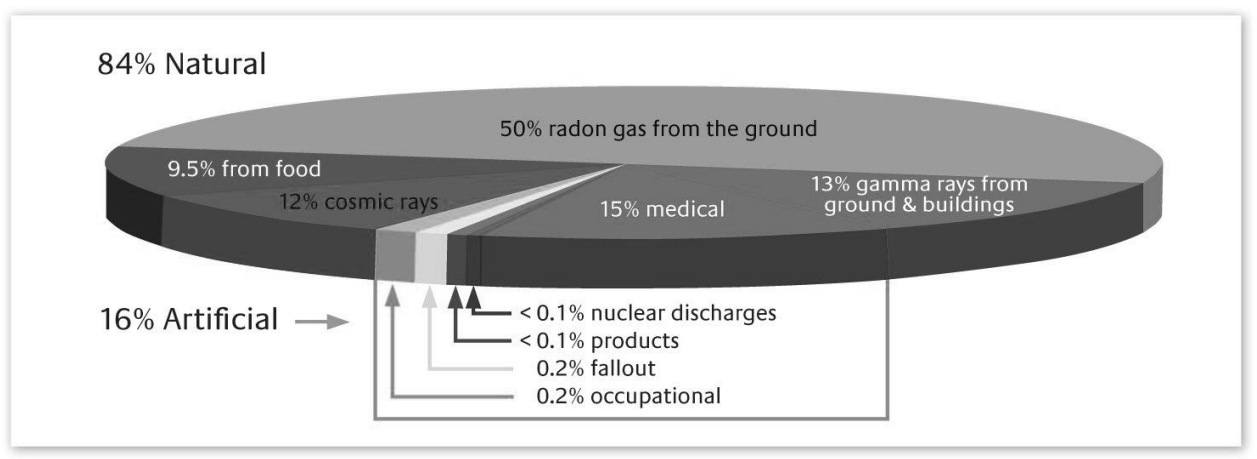

Fig. 1. Percentage share of various types of ionising radiation: natural and artificial ones, affecting the human body according to research conducted by scientists in England [co.uk/imgres - 09.2016].

Unlike other natural radionuclides, radon is a gas. It occurs in the form of the ${ }^{222} \mathrm{Rn}$ isotope in the uranium decay chain and ${ }^{220} \mathrm{Rn}$ in the thorium decay chain. The first of them is more significant due to the longer half-life period. As a noble gas, radon is not directly dangerous to human health, since it is excreted from our body relatively quickly. However, the products of its decay, especially those with a short lifetime emitting alpha particles are especially dangerous. [7] These particles are constantly formed as a result of the decay of radon in the air. After their absorption into the lungs, they are further disintegrated, which results in the respiratory tissues being exposed to an increased dose of harmful alpha radiation. This exposure has the character of a local irradiation of pulmonary tissue, which consequently induces lung cancer. On the basis of population studies among patients with lung cancer, radon radiation has been found to be a $10 \%$ risk factor for the emergence of the most difficult-to-treat cancer types. Owing to these findings, radon has become the subject of special interest and measures aimed at limiting its participation in radiation doses 
received by man. Since the contribution of radon in the induction of cancer has been proven by doctors, it has become necessary to implement preventive measures. The measures have been focused on determining the permissible level of radon concentration in the indoor air. Extensive internal air testing has been required to determine this level. It has been important to determine how far the dose of ionising radiation whose source is radon exceeds the level of the so-called background dose the human body is adapted to.

\section{The state of research}

The problem related to radon threats was first noticed at the end of the seventies. Since then, intensive research into this radiation factor has been conducted in many countries. Those studies have demonstrated that the place where people are especially exposed to this type of ionising radiation is the indoor environment in buildings. [8] As a result of research conducted as early as in the seventies, it turned out that the concentration of radon in the rooms exceeds the concentration of this gas in the immediate vicinity of the building by an average of 8 to 10 times. [9] Due to this fact, radon preventive measures introduced in many countries concentrated on investigating the causes of increased radon concentration in rooms. Among others, there are large-scale measurements performed that aim at the identification of areas and houses with a high concentration of this radionuclide.

In the first period of research conducted until around the beginning of the nineties, it was found that the average values of radon concentration in residential buildings fluctuated within $20-50 \mathrm{~Bq} / \mathrm{m}^{2}$. The continuation of the studies demonstrated, however, that there are more and more numerous cases of higher concentration levels of this gas. These values reached several hundred or even several thousand $\mathrm{Bq} / \mathrm{m}^{2}$. Such buildings were located in various places on earth, including the Scandinavian countries, the United Kingdom and the United States.

Since the very beginning of "radon" measures, scientists in our country have also dealt with this issue. At the turn of 1992 and 1993, research on the exposure of residents to radon was conducted in flats in Kraków. These tests were performed by the Department of Epidemiology and Preventive Medicine of Collegium Medicum at the Jagiellonian University in cooperation with the Air and Industrial Hygiene Laboratory from California Department of Health Services in the United States. [10] Radon concentration tests were performed only inside the buildings. No measurements concerning the concentration of this radionuclide outside buildings in the outdoor air were performed. The researchers acknowledged that the impact of this threat on human health is most significant in the rooms. On the basis of previous studies, they concluded that an increase in the concentration of radon inside rooms in relation to the immediate environment should be considered proven. Additionally, the time of human exposure to this type of radiation inside buildings is clearly longer in our climate zone.

In order to determine the reasons for the increased concentration of radon inside buildings, the research conducted at the beginning of the 1990s covered three types of residential buildings: town houses in the oldest part of Kraków that were constructed mainly of stone and bricks, large blocks of flats built of concrete slabs and small single- or multifamily detached houses. The results of the studies demonstrate that underground storeys and ground level storeys of buildings play an important role in the issue analysed. In each of the groups of facilities selected, in accordance with the arithmetic mean, the largest concentrations of radon occurred in the basements. The lowest concentrations were recorded in the basements of old town houses, and the highest ones in the basements of single-family houses. A similar situation occurred on the ground level storey. The level of radon concentration observed on the ground floor in single-family houses was about $50 \%$ higher in non-basement buildings of this type in comparison to the structures with basements. 


\section{Radon sources in rooms}

The source of radon in the indoor air in buildings is found in natural radioactive elements occurring in its surroundings, in building products manufactured from natural and waste mineral resources, and above all in the ground. The share of radon contained in building materials in the total exposure of residents to this type of ionising radiation is relatively small. The research on building materials was conducted in our country as early as in the 1970 s by the Central Laboratory for Radiological Protection, the Institute for Nuclear Research and the Power Waste Management Company. The results of those tests have been later confirmed by more and more precise measurements. Those studies indicated that wood emits the least amount of radon. Concrete, whose radioactivity results from the level of radioactivity in the aggregate, is characterized by greater emission. It is lower when aggregates are manufactured from natural minerals, and clearly higher when waste materials, especially the post-industrial ones, are used. The radioactivity of ceramic products is at a similar level and is conditioned by the radioactivity of raw materials used in their production. The highest emission of radon in our country was found in the materials whose production involved using coal combustion wastes, such as slag and fly ash, as additives, since they contain radium in a much higher concentration than the average natural materials. [9]

Currently, building materials are subject to greater control in terms of their radioactivity, therefore their influence on the level of radon in the rooms is not as significant as it was in the past, but still higher than the one being attributed to outside atmospheric air. [2]

The least significant sources of ionising radiation of radon nature in buildings are: tap water and natural gas used in households as well as external atmospheric air. [5] (Fig. 2).

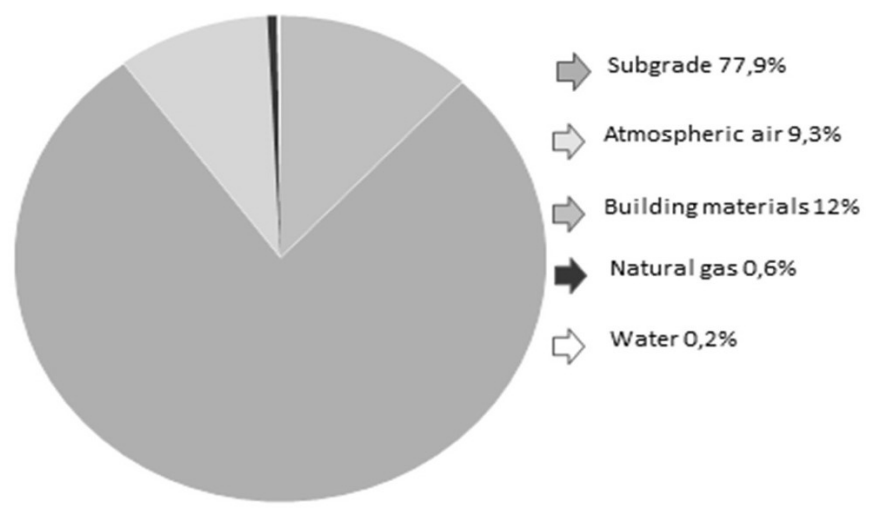

Fig. 2. Radon sources in buildings according to the research conducted in the Institute of Nuclear Physics PAS in Cracow.

According to the latest research, the main source of radon in buildings is currently the subgrade (Fig. 3). The infiltration of radon from soil into buildings is the main reason for its increased concentration in the rooms. The quantity of radon emission from the subgrade is caused by a large amount of radium in the ground under the building. The intensity of this emission is particularly high when the increased content of radium occurs in its upper layer, and the radium contained therein is characterized by a high rate of radon emanation. Being gas, radon rises towards the surface of the terrain. Both the range and rate of radon infiltration are to a large extent dependent on the soil structure. The soil with a porous structure is characterized by better permeability. Cracks, crevices and faults occurring in the rocky subgrade are conducive to infiltration of radon. 


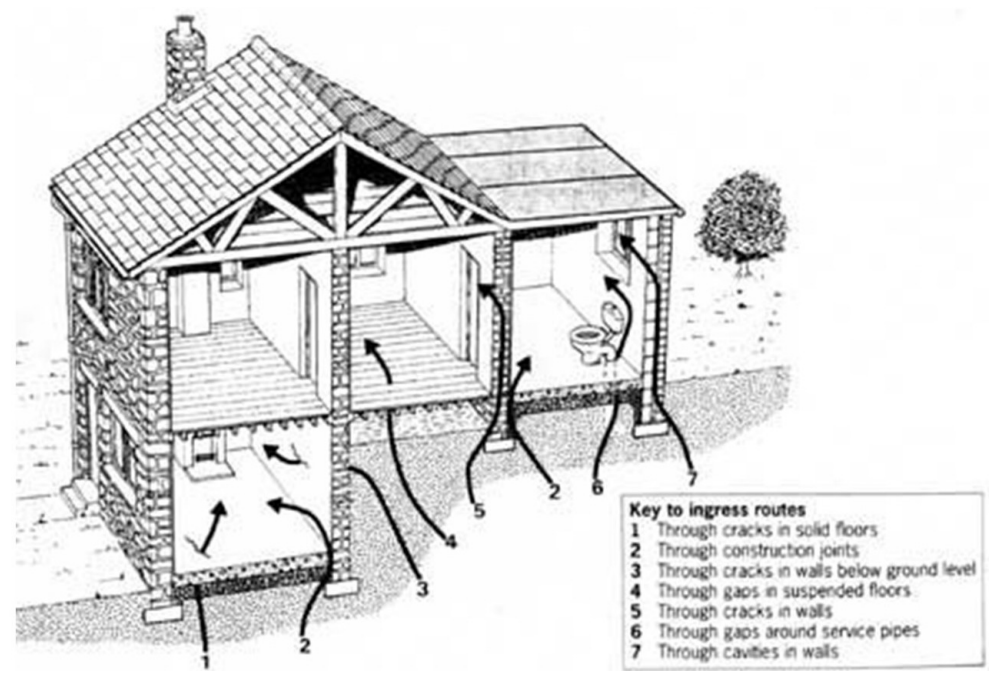

Fig. 3. Diagram of radon infiltration routes from the subgrade into the interior of the building [valeofgamorgan.gov.uk -17.04.2018].

Current research confirms earlier findings about the higher level of this radionuclide in the indoor air compared to its concentration in the air in the immediate vicinity of the building. This clearly indicates the impact of the construction structure on its accumulation inside the facilities. The building that is located on the way of radon emission absorbs and even sucks it. The suction of radon-containing ground gases to the inside of buildings is caused by the pressure difference between atmospheric air and indoor air in these environments. The penetration of these gases into a building is facilitated by openings and leaks in their construction. The rooms most exposed to radon penetration are located in the underground storeys and ground level storeys of buildings.

\section{Legal requirements}

Research on radon content in the indoor air of residential premises has shown that in many cases the level of its concentration significantly exceeds the dose of ionising radiation recognized as safe for our body. The situation occurs so frequently that, due to the negative impact of this phenomenon on human health, it is necessary to introduce legal requirements in terms of preventive measures for our health. This is supported by the recognition of radon as a risk factor in the development of diseases such as lung cancer by the medical community. [11] Therefore, in 2013, the Council of the European Union adopted Directive 2013/59 Euroatom. [12] This directive defines basic safety standards in order to protect people against risks resulting from exposure to ionising radiation exceeding the so-called background dose. According to this directive, European Union Member States are obliged to develop and implement the laws, regulations and administrative provisions necessary to implement its recommendations. These measures should be introduced by 6 February 2018 at the latest. Article 103 of the Directive provides that in order to manage long-term risks resulting from radon exposure in apartments, public buildings and at workplaces, National Radon Action Plan is created.

Much earlier, between 1995 and 2002, the Ordinance of the President of the National Atomic Agency that specified the permissible average annual concentration of radon in the air in the premises designed for permanent accommodation was in force in Poland. These values were not to exceed $400 \mathrm{~Bq} / \mathrm{m}^{3}$ in buildings built before 1998 and $200 \mathrm{~Bq} / \mathrm{m}^{3}$ in 
buildings built after 1998. [13] These requirements were in line with the recommendations of the European Commission 90/143/Euroatom. [14] Once exceedance of these values was discovered, measures to limit the concentration of radon were to be taken. The ordinance also indicated the need to perform tests aimed at indicating houses where radon levels exceeded the acceptable levels of its concentration.

In the following years, the activities devoted to protection against ionising radiation in construction focused on the problem of radioactivity of building materials. [15] The reduction in ionising radiation emitted from building materials has definitely contributed to the improvement in the quality of internal environment in terms of radon threats in buildings. However, the radioactivity of building materials is not the main source of radon in buildings. Studies show that radon concentrations in buildings still exceed its acceptable levels.

The following years did not bring significant development in terms of preventive measures against radon in buildings. It was only the Directive 2013/59/Euratom that led the European countries, including ours, to take more decisive steps in this matter. On 11 August 2014, the Minister of the Environment published the Ordinance [16] regarding the appointment of the Committee for the development of the concept of transposing the recommendations into the national legislation. These works are currently being finalised and will soon become legally binding regulations. The regulations were developed in six working thematic groups. Group II dealt with exposure to radon in buildings and radiation from building materials. As part of the work in this thematic group, the directions of the necessary protective and preventive measures have been defined. It entails such activities as: creating and testing measurement procedures, defining procedures for comparative measurements and educational and training campaigns. One of the most important tasks necessary for implementation within these activities is the so-called "new" designing of buildings. The term "new" should be understood as designing that recognises the problem of the radon threat in buildings.

\section{New aspects of architectural and construction design of residential buildings}

Research results that indicate the building zones particularly exposed to the occurrence of radon threats should lead designers to devote attention to these fragments which is clearly different from the current one. In addition to direct economic aspects, designing should also recognise such long-term consequences as the exposure of users to health loss and enormous social costs that are currently incurred for treating people. In the case of diseases caused by ionising radiation, it is an extremely expensive process of keeping a person alive rather than restoring them to health. This "new" designing should be particularly painstaking with regard to housing as we spend most of our lives in the environment of these buildings. In terms of housing construction, single-family housing, which dominates in these types of facilities in our country, is especially important.

Due to the economic aspect of single-family house construction, buildings of this type are more and more often built without a basement. In the light of research concerning radon concentration in buildings, the increased concentration of this gas found most frequently in the basements of buildings with basements is transferred to the ground floor of non-basement structures. This is due to the direct contact of this level with the subgrade that emits radon. The perfect sealing and detachment of this level is extremely difficult due to numerous necessary gaps around service pipes, such as sewage or water supply. Another problem is the protection of air supplied to the interior of buildings as part of new energysaving solutions such as the so-called "heat pump". 
In the search for an effective method of protection against infiltration of radon into the building, efforts are made in many Western countries to identify areas where an increased emission of this radionuclide from the subgrade occurs. For this purpose, the so-called "radon maps" are created that indicate areas where housing construction should not be located. These activities are extremely expensive and, according to physicists from the Institute of Nuclear Physics in Kraków, not the most effective ones. There may be both a region with clearly increased radon emission and a region with limited emission of this radioactive gas even within one plot. The geological structure has a significant influence on the possibility of radon emission from the subgrade. For example, sealed clay deposits significantly impede the diffusion of radon. In contrast, cracks in the bedrock create "nozzles" that accumulate the stream of this gas and locally create an area with a very high emission from the subgrade. Therefore, even two buildings located at a small distance from each other can clearly differ in terms of radon threats occurring in their interior. [13]

In Western countries, the so-called "radon pumps" are applied in facilities where an increased level of radon was discovered. Those are devices that suck this gas from the ground located under the building and remove it to the atmosphere above its roof (Fig. 4). In exceptional situations, such devices are also used to remove air with an increased content of radon from basement rooms (Fig. 5). These solutions are extremely effective, but also energy-consuming due to the need for their continuous operation. In the era of energysaving construction, it is therefore a solution that does not fully meet the requirements of this type of construction.

The tests performed in the rooms have indicated that the concentration of radon in the indoor air clearly decreases at the moment of opening the windows, which increases their natural ventilation. It seems that a properly ventilated basement is a perfect protection of higher, residential storeys against the penetration of this gas into their interior. This solution can be considered as proven in the light of previous studies which demonstrated that the concentration of radon in the ground level storeys of buildings with a basement is clearly lower than its concentration in the ground level storeys of buildings without basements.

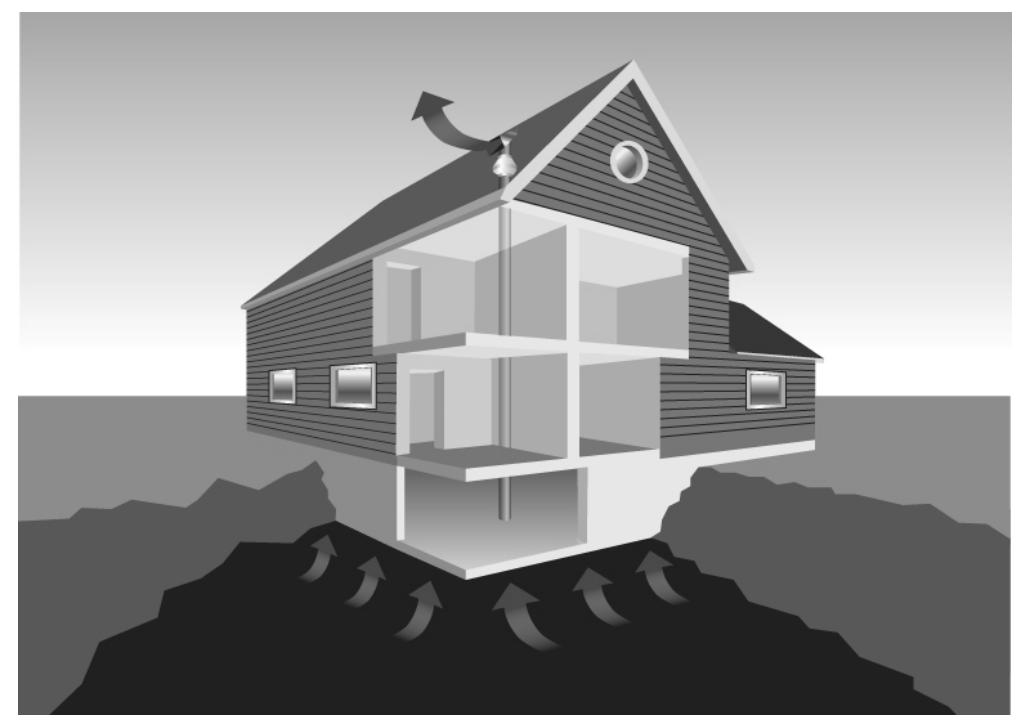

Fig. 4. Diagram of radon pump operation that removes radon from the ground located under the building [bridaldesignstudio.co.uk - 17.04.2018]. 


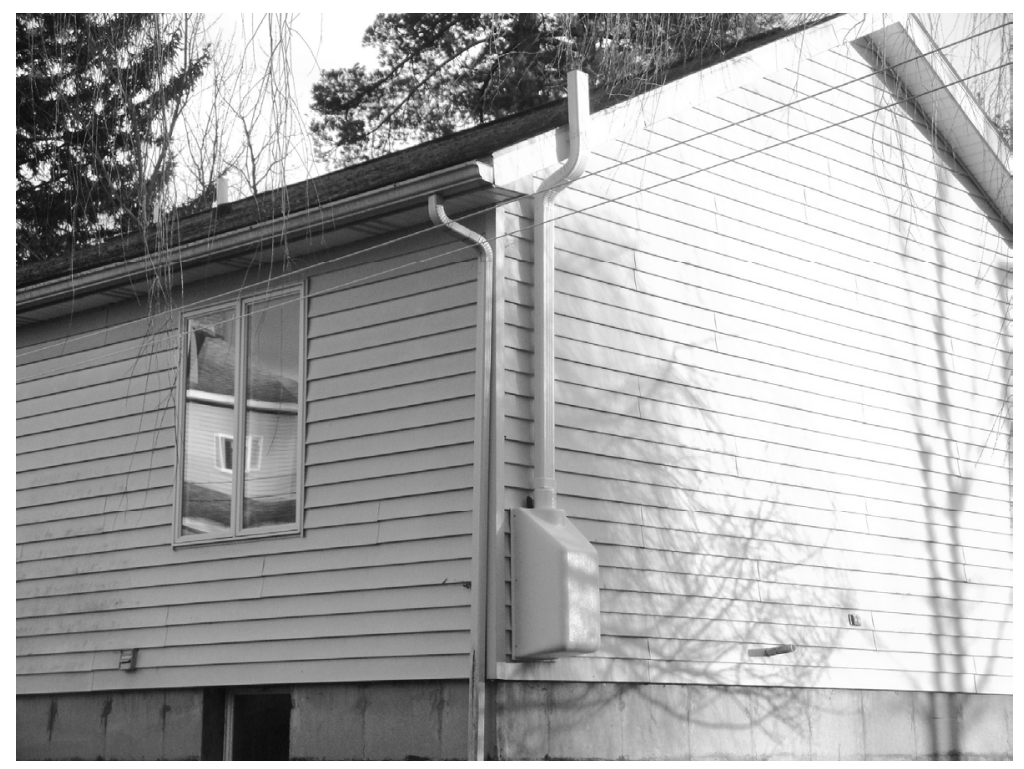

Fig. 5. A radon pump that removes air contaminated with radon from the basement of the building [highlandairinc.com - 17.04.2018].

\section{Conclusions}

Recognition of harmful effects that radioactive gas such as radon emitted from the ground has on human health imposes a new scope of requirements in the design of residential buildings. Meeting the biological needs of the human body is one of the basic aims of the architect's profession. The accomplishment of this task entails not only the creation of comfortable environmental conditions in buildings in terms of thermal physical factors, but also the protection of this environment from harmful physical, biological and chemical factors. This requires constant updating of the architect's professional skills and including knowledge about health risks in the indoor environment in one's design decisions. Medical research has demonstrated that the concentration of radon in the air exceeding the background dose is extremely harmful to the human body. Measurements conducted by nuclear physicists demonstrate that the interior of the building is conducive to the accumulation of this radioactive gas, while its material structure can be the source of its emission. These studies indicate a close relationship between the increased concentration of radon in the indoor air and the level on which the room is situated in relation to the ground level. The location of residential premises directly on the so-called ground constitutes a major obstacle to protecting their environment from the infiltration of radon. The basement in the building and the placement of residential premises above ventilated basement rooms provides the opportunity to remove excess gas before it penetrates the higher levels. A ventilated sub-floor space could be an alternative and less expensive procedure. Even if the tests concerning radon emissions from soil conducted at the site of the future location of a residential building do not indicate a significant exceedance, there is still no agreement as to whether this is a stable situation or whether it may change to a more or less unfavourable one in the future. Therefore, when designing and constructing a new building, one should take into account the possibility of the occurrence of such a situation and use such architectural and construction solutions that enable the interior of the building to be protected against the possibility of radon threats. 


\section{References}

1. T. Kusionowicz, Problemy projektowania budynków mieszkalnych a zdrowie człowieka. Wybrane zagadnienia. (Monograph 363, CUT, Kraków, 2008)

2. L. Brunarski, Promieniowanie jonizujace - zagrożenie użytkowników pomieszczeń. (Proceedings from the $4^{\text {th }}$ Conference on Internal Air Quality Problems in Poland'97. Warsaw, November 1997, Warsaw University of Technology, Warsaw, 7-21,1998)

3. L.H. Toburen, Elektromagnetic fields, radon and cancer, The Lancet. 347, 1996; www.epa.gov/iag/radon/pubs/index,html

4. M. Dohojda, Wpływ stężenia aktywności radonu na jakość powietrza wewnętrznego. Problemy jakości powietrza wewnętrznego w Polsce 2003 (Wydawnictwo Instytutu Ogrzewnictwa i Wentylacji Politechniki Warszawskiej, 53-60, 2004)

5. K. Danyłec, Radon w środowisku. (Paper presented at the popular science session of the Laboratory of Radiological Expertise of the Institute of Nuclear Physics PAS in Kraków on Radon Day, Kraków, 6 November 2015)

6. J.A. Rubin, Promieniowanie naturalne $w$ środowisku mieszkalnym czlowieka. (Proceedings from the Symposium Architecture, technology and health. Silesian University of Technology, Gliwice, 105-114, 2003)

7. T. Niewiadomski, O promieniowaniu jonizujacym popularnie, (PZWL, Warszawa, 1991)

8. H. Batura-Gabryel, Nowa Klinika, 1-2, 5 (2005)

9. Aspekty zdrowotności materiałów budowlanych, (scientific expertise developed by a team led by W. Muszyński, Section of Materials Applications in Construction, Committee of Civil and Water Engineering, Polish Academy of Sciences, Warsaw, 1979)

10. W. Jędrychowski, E. Flak, J. Wesołowski, L. Kai-Shen, Poziom radonu w mieszkaniach budynków o starej i nowej zabudowie na terenie Krakowa. (Proceedings from the 4th Conference on Internal Air Quality Problems in Poland'97. Warsaw, November 1997, Warsaw University of Technology, Warsaw, 55-64, 1998)

11. F.E. Speizer, Choroby pluc wywołane działaniem środowiska (A.S. Frauci, E. Braunwald, K.J. Isselbacher, J.D. Wilson, J.B. Martin, D.L. Kasper, S.L. Hauser, D.L. Longo (ed.) Interna Harisona, II, 1879-1889, 2001)

12. Council Directive 2013/59/Euratom of 5 December 2013 laying down basic safety standards for protection against the dangers arising from exposure to ionising radiation, and repealing Directives 89/618/Euratom, 90/641/Euratom, 96/29/Euratom, 97/43/Euratom and 2003/122/Euratom. Official Journal of the European Union of 17 January (2014)

13. K. Kozak Prace nad projektem przepisów $w$ prawie krajowym zwiazanych z wprowadzeniem Dyrektywy Rady Unii Europejskiej 2013/ 59 /EUROATOM, paper presented at the popular science session of the Laboratory of Radiological Expertise of the Institute of Nuclear Physics PAS in Kraków on Radon Day, Krakow, 6 November (2015)

14. Council Directive 96/29/Euratom of 13 May (1996)

15. Cabinet of Ministers Regulation of January 2, 2007 on the requirements for the content of natural radioactive isotopes of potassium K-40, Ra-226 radium and thorium Th-228 in raw materials used in buildings designed to accommodate people and livestock, as well as industrial waste used in construction, and control of these isotopes. Dziennik Ustaw No. 4, item 29.

16. Ordinance of the Minister of the Environment of August 8, 2014 regarding the appointment of the Team for the development of the concept of transposing the Directive 2013/59/Euratom into the national legislation, Dziennik Urzędowy Ministra Środowiska, 2014, item 50 